\title{
Das Chaperon-Protein FKBP5: Target zur Verbesserung der Stressresistenz
}

Stress und traumatischen Erfahrungen im Kindes- und Erwachsenenalter sind mit die stärksten Risikofaktoren für eine spätere Entwicklung von psychiatrischen $\mathrm{Er}$ krankungen, insbesondere von Angstund Depressionsstörungen. Aber nicht jeder erkrankt nach solchen Erfahrungen. Ein besseres Verständnis der Faktoren, die Stressresistenz oder Stress-Suszeptibilität beeinflussen, könnte neue Präventionsund Behandlungsstrategien für psychiatrische Erkrankungen aufdecken. In diesem Vortrag soll ein solcher Mechanismus beleuchtet werden. Das Chaperon-Protein FKBP5 ist eng in die Regulation der StressAntwort eingebunden. In einer Vielzahl von Studien konnte gezeigt werden, dass genetische Varianten in dem Gen, das für dieses Protein kodiert, die Folgen von Trauma in der Kindheit für eine Reihe von psychiatrische Erkrankungen im Erwachsenenalter moderieren. In einer Reihe von
Experimenten, konnte ein möglicher Mechanismus für diese Gen x Umwelt-Interaktionen aufgezeigt werden. Eine genetische und eine epigenetische Enthemmung von FKBP5-Transkription müssen zusammenkommen, damit das Risiko ansteigt. Über direkte Protein-Protein-Interaktionen führt diese gesteigerte FKBP5 Produktion dann zur Veränderung einer Reihe von Signalwegen, die für neuronale Funktionen wichtig sind, wie zum Beispiel BDNF, TauProteine und Calcineurin. In diesem Vortrag wird erläutert, dass Patienten mit einer genetisch und epigenetisch enthemmten Transkription von FKBP5 eine transdiagnostische Subgruppe an Patienten darstellen könnte. Diese Patienten könnten von Antagonisten des FKBP5 profitieren, die in Tierversuchen erste vielversprechende Ergebnisse bei der Reduktion von Stressfolgen gezeigt haben.
Interessenkonflikte

Forschungsgrant von Böhringer-Ingelheim zu FKBP5 Funktion

Autor

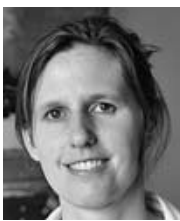

Elisabeth Binder Direktorin, Abteilung für translationale Forschung in der Psychiatrie, Max-Planck-Institut für Psychiatrie, München

Korrespondenzadresse

Prof. Dr. Dr. Elisabeth Binder

Direktorin

Abteilung für translationale Forschung

in der Psychiatrie

Max-Planck-Institut für Psychiatrie

Kraepelinstraße 2-10

80804 München

binder@psych.mpg.de 